\title{
THE DEAD SEA ECOSYSTEM INFLUENCED BY RED SEA - DEAD SEA CONDUIT PROJECT (PEACE CONDUIT)
}

\author{
Moh'd WEDYAN *, Ahmed EL-OQLAH **, Khalil ALTIF *** and Khalid KHLIFATE **** \\ * The Hashemite University, Biological Sciences and Biotechnology Department, Al Zarka, P.O. Box \\ 330127, Jordan, mohwedyan@gmail.com \\ ** Yarmouk University, Irbid, Biology Department, P.O. Box 566, Jordan, el-oqlaha@yu.edu.jo \\ *** Al Hussien bin Talal University, Ma'an, Biology Department, P.O. Box 20, Jordan, \\ kialtaif@yahoo.com \\ **** Mutah University, Biology Department, Al Karak, Jordan, alkhkha@mutah.edu.jo
}

DOI: $10.2478 /$ trser-2013-0019

KEYWORDS: Red Sea, Dead Sea, Peace Conduit, ecosystem impact, Jordan.

\section{ABSTRACT}

Recently, the rapid drying out of the Dead Sea is one of the most challenging problems facing the scientists and governments of the region. Its level has dropped more than $20 \mathrm{~m}$ in the past decade. Massive precipitation of halite from the water column has led to a decrease in $\mathrm{Na}^{+}$concentration, concomitant with an increase in $\mathrm{Mg}^{2+}$, making the lake supersaturated with $\mathrm{NaCl}$. This situation presents a big challenge to the microbial life of the lake. However, despite these harsh conditions in the lake, several microorganisms, including members of the groups bacteria, unicellular algae, fungi, viruses, and Archaea, have been able to survive.

To understand the factors that affect the microbes in the Dead Sea and to predict the possible effects of the planned conveyance of Red Sea water to the Dead Sea, a series of experiments were performed in the field, as well as in the laboratory. The results of the laboratory experiments showed that the growth of the Dunaliella was possible only when Dead Sea water was diluted with a minimum of $10 \%$ (by volume) Red Sea water. Addition of phosphate was essential for the algae to grow and growth rates and yields increased with increasing phosphate concentration and decreasing salinity. Field experiments revealed that the growth of algae was rapidly followed by the development of dense blooms of red halophilic Archaea. Although it should be realized that the closed system formed by the shallow ponds differs from the conditions in the lake, the results suggest that a microbial bloom, once formed, can remain present in the Dead Sea for months to years. These observations are important when attempting to predict how the biological properties of the lake may change in the future and they have important implications for the planning of the Red SeaDead Sea conduit.

The "Peace Conduit", a water carrier between the Red Sea and the Dead Sea, has been proposed to prevent the drying out of the lake and to restore the water level to a desired elevation. The present simulation experiments were designed at the Al Hussein bin Talal University (AHU) field station at Ma'an to get information on the ecological impacts of the Dead Sea when the "Peace Conduit" plans are implemented and massive quantities of Red Sea water will enter the Dead Sea and lower the salinity of the upper water layers.

Preliminary analysis was carried out of Fluorescence In Situ Hybridization (FISH) and Polar lipid of Archaea and Bacteria collected from the experimental ponds containing different Dead Sea-Red Sea water ratios, in order to analyze how they affect the microbial communities of the ponds. The Archaea community changed significantly according to the water mixture, presenting the greatest diversity when $30 \%$ Red Sea water was added to Dead Sea water. 
ZUSAMMENFASSUNG: Das Ökosystem des Toten Meeres unter dem Einfluss des Roten Meeres - das Tote Meer Leitungsprojekt (Friedens-Leitung).

Neuerdings ist das rasche Austrocknen des Toten Meeres das herausforderndste Problem, dem die Wissenschaftler und Gouverneure gegenüberstehen. Sein Wasserspiegel sank im vergangenen Jahrzehnt um mehr als $20 \mathrm{~m}$. Da der massive Halit Regen von der Wassersäule zu einer Verringerung der Konzentration von $\mathrm{Na}^{+}$mit einem gleichzeitigen Steigen von $\mathrm{Mg}^{2+}$ geführt hat, kommt es im Meer zu einer Übersättigung von $\mathrm{NaCl}$. Diese Situation führte zu großen Schwierigkeiten für das mikrobielle Leben. Trotz dieser rauen Bedingungen haben einige Mikroorganismen, einschließlich aus dem Bereich der Bakterien, einzelligen Algen, Pilze, Viren and Archaea überlebt.

Um die Faktoren, die Mikroben im Toten Meer beeinträchtigen und die Auswirkungen der geplanten Verbindung zwischen dem Wasser des Roten Meeres mit dem Toten Meer zu verstehen, wurde sowohl im Freiland als auch im Labor eine Reihe von Experimenten durchgeführt. Die Ergebnisse der Laborexperimente zeigten, dass das Wachstum von Dunaliella nur dann möglich war, wenn das Wasser des Toten Meeres um Minimum 10\% (entsprechend dem Volumen) mit Wasser des Roten Meeres verdünnt wurde. Die Zugabe von Phosphat war wesentlich für das Wachstum der Algen, wobei Wachstumsrate und Produktion mit steigender Phosphatkonzentration und abnehmender Salzkonzentration anstiegen. Die Freilanduntersuchungen zeigten, dass dem Wachstum der Algen rasch eine dichte Blüte der roten halophilen Archaea folgte. Obwohl man einsehen muss, dass das geschlossene Niedrigwassersystem der Teiche sich von den Bedingungen im Meer unterscheidet, zeigte sich, dass eine mikrobielle Blüte, einmal ausgebildet, sich längere Zeit über Monate bis zu Jahren im Toten Meer halten kann. Die Beobachtungen sind wichtig, wenn man sich anschickt vorauszusagen, wie sich die biologischen Eigenschaften des Meeres in Zukunft verändern könnten. Außerdem haben sie wichtige Konsequenzen für die Planung der Rohrleitung zwischen Rotem und Totem Meer.

Die "Frieden-Leitung”, der Bau einer Wasserleitung zwischen dem Roten und dem Toten Meer wurde vorgeschlagen, um das Austrocknen des Meeres zu verhindern und den Wasserstand in einer gewünschten Höhe wiederherzustellen. Die gegenwärtig durchgeführten, im Feldlabor der Al Hussein bin Talal Universität (AHU) geplanten Simulationsversuche, sollen Informationen liefern zu den ökologischen Auswirkungen auf das Tote Meer, wenn die Pläne der "Friedens-Leitung" umgesetzt werden und beträchtliche Mengen von Wasser aus dem Roten Meer in das Tote Meer fließen werden, wobei der Salzgehalt der oberen Wasserschichten gesenkt wird.

Die vorläufige durchgeführte Analyse der Fluoreszenz-In-Situ-Hybridisation (FISH) und der Polar-Lipede von Archaea sowie Bakterien, die aus den Experimentierungsteichen mit unterschiedlichem Anteil aus dem Roten Meer entnommenen Wassers beschickt wurden, zeigt, dass die Archaea Gemeinschaft sich je nach Wassergemisch signifikant verändert hat und dann die höchste Diversität aufweist, wenn 30\% Wasser aus dem Roten Meer zu dem aus dem Toten Meer hinzugefügt wird.

REZUMAT: Influența proiectului „Conducta Marea Roșie-Marea Moartă” (Conducta Păcii) asupra ecosistemului Marea Moartă.

În ultimii ani, evaporarea rapidă a Mării Moarte este una dintre cele mai dificile probleme cu care se confruntă oamenii de știință și guvernele din regiune. Nivelul acesteia a scăzut cu peste $20 \mathrm{~m}$ în ultimii zece ani. Precipitările masive de halit din coloana de apă au dus la o creștere a concentrației ionilor de $\mathrm{Na}^{+}$concomitent cu creșterea concentrației ionilor de $\mathrm{Mg}^{2+}$, ducând la suprasaturarea lacului cu $\mathrm{NaCl}$. Această situație reprezintă o mare provocare 
pentru viața microbiană a lacului. Cu toate acestea, în ciuda condiților dificile din lac, unele microorganisme, inclusiv membrii ai grupului Bacteria, alge unicelulare, fungi, viruși și arhee au reușit să supraviețuiască.

Pentru a înțelege factorii care au influențat microorganismele din Marea Moartă și pentru a putea prezice posibilele efecte ale aportului preconizat de apă din Marea Roșie în Marea Moartă, s-au efectuat o serie de experimente atât pe teren cât și în laborator. Rezultatele experimentelor în laborator au arătat că Dunaliella poate să se dezvolte numai la o diluție volumetrică a apei din Marea Moartă cu minim 10\% apă din Marea Roșie. Adăugarea de fosfați a fost esențială pentru ca alga să se dezvolte, iar randamentele au crescut odată cu creșterea concentrației de fosfați și scăderea salinității. Experimentele de teren au arătat că dezvoltarea algelor a fost rapid urmată de înfloriri de mare densitate ale unor arhee halofile roșii. Deși trebuie luat în considerare faptul că sistemele închise formate de iazurile superficiale nu reproduc întocmai condițiile din Marea Moartă, rezultatele sugerează că înfloririle algale, odată formate, pot rămâne în Marea Moartă timp de luni şi chiar ani de zile. Aceste observații sunt importante pentru încercarea de a prezice modul în care se pot modifica proprietățile biologice ale lacului și au implicații majore pentru planurile de construcție a conductei Marea Roșie - Marea Moartă.

Proiectul „Conducta Păcii”, construcția unui apeduct între Marea Roșie și Marea Moartă a fost propus pentru a preveni secarea lacului și pentru a readuce nivelul apei la cota dorită. Experimentele de simulare efectuate până în prezent au fost create la stațiunea de cercetări a Universității Al Hussein bin Talal (AHU), cu scopul de a testa informațiile cu privire la impactul ecologic asupra Mării Moarte după punerea în practică a planurilor pentru „Conducta Păcii”, atunci când cantități masive de apă din Marea Roșie vor intra în Marea Moartă și salinitatea straturilor superficiale va scădea.

Analizele preliminare au fost efectuate cu protocolul (FISH) - Fluorescence In Situ Hybridization și prin studiul lipidelor polare la arhee și bacterii colectate din iazurile experimentale ce conţin diferite procentaje de apă din Marea Moartă și Marea Roşie pentru a putea analiza modul în care aceste amestecuri afectează comunitățile microbiene din lacuri. Comunitățile de Archaea s-au modificat semnificativ odată cu schimbarea amestecului de apă, având cea mai mare diversitate la un procent de 30\% apă din Marea Roșie adăugată în apă din Marea Moartă.

\section{INTRODUCTION}

The Dead Sea is a terminal lake located on the border between Jordan and Israel and it is part of a larger geological system known as the Jordan Rift valley. The lake consists of a deeper northern basin (deepest point at $\sim 725 \mathrm{~m}$ below sea level) and a southern basin which has dried up and is being used for commercial mineral production. Until 1979 the Dead Sea was a meromictic lake with hypersaline, anoxic and sulphidic deep waters and a seasonally varying mixolimnion (Anati et al., 1987). The Jordan River and winter rain floods are the main sources of water input. Since the beginning of the 20th century the water budget of the Dead Sea has been negative, leading to a continuous decrease in Sea level (Anati et al., 1987; Oren, 2010). The extensive evaporation in the absence of major water sources led to an increase in the water density which caused the lake to overturn in 1979 (Steinhorn et al., 1979). Since then the Dead Sea remained holomictic and has been characterized by a constant state of $\mathrm{NaCl}$ supersaturation and halite deposition on the lake bottom. The decrease in $\mathrm{Na}^{+}$ions has led to an increase in $\mathrm{Mg}^{++}, \mathrm{Ca}^{++}$and other dissolved ions. 
During the 20th century, the Dead Sea level has dropped by more than $20 \mathrm{~m}$ and during the past decade, the level has dropped about one m per year on average (Gavrieli et al., 2002, 2005, 2005; Dvorkin et al., 2007). Severe problems affecting local infrastructure, tourism and industrial activities are caused by the phenomena (Oren et al., 2004). Due to the precipitation of halite, the total salt concentration has remained approximately constant at around $340 \mathrm{~g} \mathrm{l}^{-1}$ and the $\mathrm{pH}$ at about six.

The increased salinity and the elevated concentration of bivalent ions make the Dead Sea too extreme and harsh environment to be tolerated by most organisms.

The life within the lake has been subjected to extensive research since the 1930s when Benjamin Elazari-Volcani (Wilkansky, 1936) isolated the first microorganisms from the sediments. Besides bacteria and Archaea, these isolates included algae (Elazari-Volcani, 1943 a), protozoa (Elazari-Volcani, 1943 b) and ciliates (Elazari-Volkani, 1944). Since then, several bacteria and Archaea isolates have been obtained in culture both from the sediment and from the water body (Oren, 2010). In comparison to other water bodies, the general abundance of organisms in the Dead Sea is very low. Two notable exceptions were two blooms in 1980 and 1992, when after severe winters, the upper meter of the water column was diluted by $15-30 \%$ and the cell concentration reached 20-35 x $10^{6}$ cells/ml (Oren and Gurevich, 1995). The first metagenomic study on the planktonic community of the Dead Sea was recently conducted and showed Archaeal dominance in the water body (Bodaker et al., 2010). A comparison between the residual microbial community in the Dead Sea in 2007 and that followed the algal bloom in 2007 showed a marked differences between microbial communities.

Following rainy winters in 1980 and 1992, dense microbial blooms were observed in the Dead Sea. The formation of pycnocline at a depth varying between five and about $15 \mathrm{~m}$ was caused by the dilution of the upper water layers (Gavrieli et al., 1999). Oren et al. (1999 a, b), estimated that the algal density reached values up to $9 \times 10^{3}$ and $1.5 \times 10^{4}$ Dunaliella cells $\mathrm{ml}^{-1}$ in 1980 and 1992, respectively. Beside the algal blooms, red halophilic Archaea rapidly developed in high numbers; $2 \times 10^{7}$ and $3.5 \times 10^{7}$ Archaea $\mathrm{ml}^{-1}$ in 1980 and 1992, respectively.

These converted the entire lake to a red colour, and ended with the termination of the meromictic state and the renewed overturn of the water column (Oren and Anati, 1996). Not only is dilution a key point, but also the concentration of phosphate may have a main role as a limiting growth factor in the Dead Sea (Oren et al., 2004).

Since the last microbial bloom in the year 1992, and with the continuous drying out accompanied by a dramatic increase in the divalent/monovalent cation ratio, the lake has become ever more an extreme biotope (Bodaker et al., 2010).

As was demonstrated by Bodaker et al. (2010), the Dead Sea still supports the life of small Archaea and bacteria species communities, but conditions have probably become too extreme for active growth. Dunaliella, on the other hand, has not been seen in the water column during the past 12-13 years.

The planned water carrier between the Gulf of Aqaba (Red Sea) and the Dead Sea was proposed to minimize the drying out of the Dead Sea and to restore the water level to a desired situation. This idea has been discussed many times and the implementation of the project "Peace Conduit" could become real after the peace treaty between Jordan and Israel was signed in 1994 (Oren, 1999 a; Oren et al., 2004). 
Peace conduit can be used for seawater desalination by using the reverse osmosis and the difference in elevation of about $416 \mathrm{~m}$ between the two seas. The formation of a stratified water column due to the dilution of the upper water layers of the Dead Sea resulted from the introduction of seawater from the Gulf of Aqaba (about $40 \mathrm{~g} / \mathrm{l}$ salts), whether or not concentrated in the reverse osmosis process, into the Dead Sea (> $340 \mathrm{~g} / \mathrm{l}$ total dissolved salts) (Oren et al., 2004).

This is a careful planned study on all aspects with positive and negative effects of the future implementation of the "Peace Conduit" regarding to the ecology of the lake. For this purpose, simulation pond experiments (Fig. 1) are being conducted on the grounds of the AHU, in experimental ponds (150 l) containing mixtures of Dead Sea water and Red Sea water (Fig. 2).

The ponds' specific conditions were periodically altered to evaluate the effects on the microbial community. Some of the parameters studied were dependent on the mixing ratios of the water mixtures, enriched with low phosphate concentrations; total water volume were lowered naturally by evaporation or constantly maintained through inflow of fresh water.

Oren and his team (2004) showed that, when phosphate was provided, even a moderate dilution of the Dead Sea (with 15\% Red Sea water) could give rise to extensive microbial blooms. Dramatic biological effects were observed in those ponds that had been filled with a mixture of $70 \%$ Dead Sea water and 30\% Red Sea water. Algae and bacteria started to appear after 1.5-2 months even when no phosphate was added. The water in the ponds became highly turbid and red-brown coloured, mainly due to archaeal bacterioruberin pigments. In the experiment of Elevi Bardavid and his colleagues (2007 a), it has been observed that the microorganisms do not normally proliferate in the lake's natural conditions, but the dilution of the Dead Sea may have dramatic effects on its microbial community.

The main goals of this research were to answer the following issues: the question of whether plankton that may enter the Dead Sea by the Peace Conduit contain available phosphate in concentrations sufficient to trigger algal blooms in the Dead Sea, a series of outdoor pond experiments were initiated at AHU in January 2011 in which different amounts of plankton collected from the Gulf of Aqaba were added to ponds filled with $80 \%$ Dead Sea water and 20\% Red Sea water, to assess the simulating effects of a reduction in salinity by adding the necessary amount of seawater, thus allowing predictions of how the biological properties of the Dead Sea ecosystem will change in the future. Another purpose is to evaluate the environmental impact of the implementation of the Peace Conduit on the Dead Sea in the future.

\section{MATERIALS AND METHODS}

\section{Experimental work}

The open field-scale experiments, based on the mixtures of Dead Sea water and Red Sea water in different ratios are shown in table number 1 , were incubated in experimental ponds on the grounds of the al Hussein bin Talal University (Fig. 1).

The experimental setup consisted of plastic tanks (150 l), which were buried in the ground at $75 \%$ of their heights (Fig. 2). 


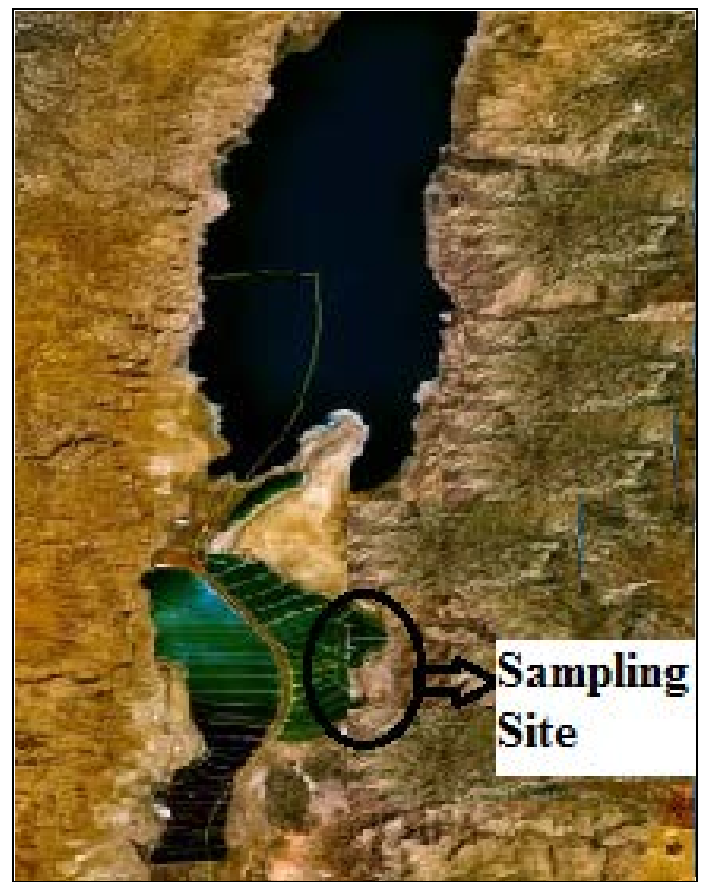

Figure 1: The location of the experimental ponds.

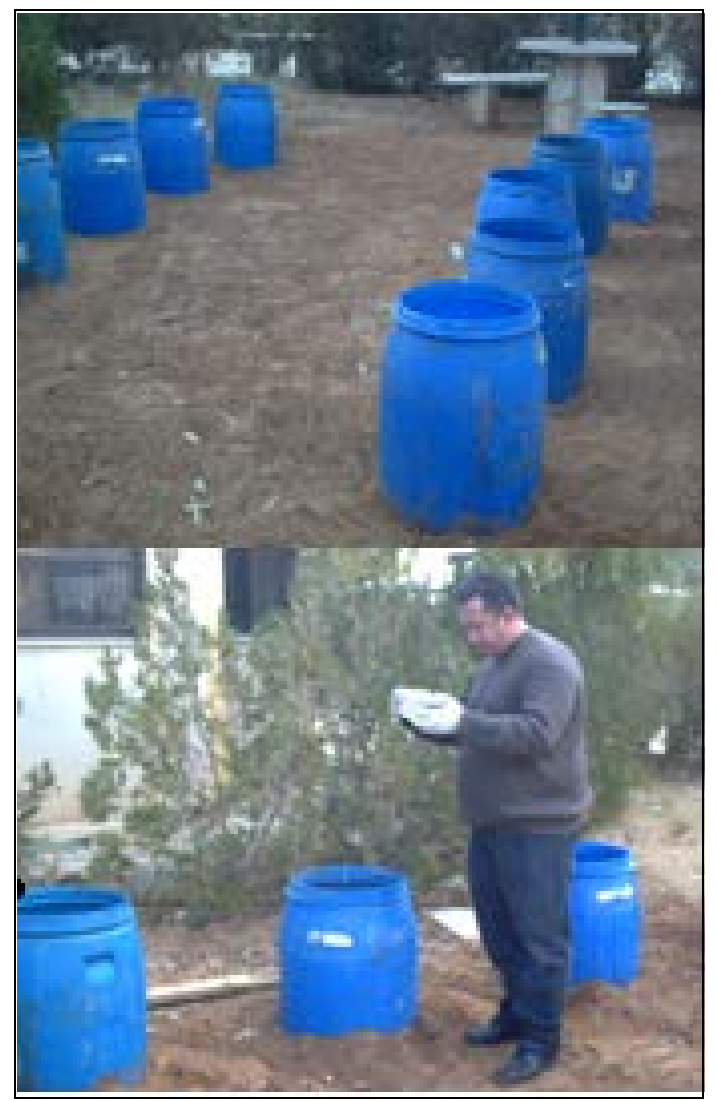

Figure 2: Tanks used for different mixtures of water. 
These tanks were filled with $100 \mathrm{l}$ of different mixtures of the Dead Sea water and water from the Red Sea (Gulf of Aqaba) as shown in table number 1.

Table 1: The proportions of Dead Sea and Red Sea (Gulf of Aqaba) waters in the water mixtures examined.

\begin{tabular}{|c|c|c|}
\hline $\begin{array}{c}\text { Pond } \\
\text { number }\end{array}$ & $\begin{array}{c}\text { Dead sea } \\
(\%)\end{array}$ & $\begin{array}{c}\text { Red Sea } \\
(\%)\end{array}$ \\
\hline 1 & 100 & 0 \\
\hline 2 & 90 & 10 \\
\hline 3 & 90 & 10 \\
\hline 4 & 90 & 10 \\
\hline 5 & 85 & 15 \\
\hline 6 & 85 & 15 \\
\hline 7 & 85 & 15 \\
\hline 8 & 70 & 30 \\
\hline 9 & 70 & 30 \\
\hline 10 & 70 & 30 \\
\hline
\end{tabular}

The data of the present report were started in January 2011 and were based on ten ponds; each was amended with one $\mu \mathrm{M} \mathrm{KH}_{2} \mathrm{PO}_{4}$ and inoculated with five $\mathrm{ml}$ of brine from a flask that had developed a bloom of Dunaliella and halophilic Archaea in a previous set of experiments.

The ponds were stirred daily and their water levels were kept constant by adding distilled water every one-two days, followed by thorough mixing. The ponds were then sampled for the content of algal chlorophyll and archaeal pigments once every week. Table 2 presents the ion concentration analyses of the samples withdrawn from the ponds.

Table 2: The ion concentration of the specific samples withdrawn from the studied ponds.

\begin{tabular}{|c|c|c|c|c|c|}
\hline \multicolumn{6}{|c|}{ Concentration $(\mathrm{ppm})$} \\
\hline Mixture of Dead Sea-Red Sea water & $\mathrm{F}$ & $\mathrm{Cl}$ & $\mathrm{Br}$ & $\left(\mathrm{NO}_{3}\right)$ & $\left(\mathrm{SO}_{4}\right)$ \\
\hline $100 \%$ & 358 & 172095 & 4999 & $\mathrm{ND}$ & 172 \\
\hline $90 \%$ & 335 & 166434 & 3762 & $\mathrm{ND}$ & 205 \\
\hline $85 \%$ & 234 & 148572 & 3190 & $\mathrm{ND}$ & 352 \\
\hline $80 \%$ & 241 & 148131 & 3378 & $\mathrm{ND}$ & 215 \\
\hline
\end{tabular}

\section{water mixtures \\ Laboratory-scale experiments of microbial growth in the Dead Sea - Red Sea}

To investigate in depth the effect of salinity and phosphate concentration on the growth of Dunaliella in the Dead Sea - Red Sea waters, a series of lab experiments were set up, in which $100 \mathrm{ml}$ Erlenmeyer flasks were filled with $75 \mathrm{ml}$ of mixtures of Dead Sea water and filtered Red Sea water at different ratios based on table 1. All flasks were inoculated with a culture of Dunaliella and incubated at $30^{\circ} \mathrm{C}$ under constant illumination by white fluorescent tubes. To prevent evaporation and to ensure constant salinity for the duration of the experiment, the flasks were closed with screwed cork. After 25 days samples were taken for the chlorophyll assay. 


\section{Pigments determinations}

The chlorophyll and other pigment contents in the experimental ponds were determined by filtering $50 \mathrm{ml}$ of the sample volume through glass fibber filters (Whatman $\mathrm{GF} / \mathrm{C}, 47 \mathrm{~mm}$ diameter) within hours after sampling. Filters were kept at $-10^{\circ} \mathrm{C}$ in the dark until further processing within three-four weeks. Filters were then extracted overnight in five $\mathrm{ml}$ methanol/acetone (1:1, by volume). For the determination of chlorophyll in laboratory cultures, $30 \mathrm{ml}$ volume of liquid were filtered through $25 \mathrm{~mm}$ diameter $\mathrm{GF} / \mathrm{C}$ filters and the filters were extracted in $2.5 \mathrm{ml}$ of methanol/acetone. The extracts were cleared of particles by centrifugation and their absorption spectra $(400-700 \mathrm{~nm})$ was measured by spectrophotometer, using the solvent as a blank. Chlorophyll concentrations were calculated based on a specific absorption of $73.5 \mathrm{l} \mathrm{mg}^{-1} \mathrm{~cm}^{-1}$ for chlorophyll $a$ at $665 \mathrm{~nm}$.

Archaeal bacterioruberin pigments were quantified based on a specific absorption of $25.4 \mathrm{l} \mathrm{mg}^{-1} \mathrm{~cm}^{-1}$ at $496 \mathrm{~nm}$ for $\alpha$-bacterioruberin. A correction was made for the contribution of algal pigments to the total absorbance at this wavelength, as outlined in Oren et al. (2004).

\section{Microbial Diversity}

FISH (Fluorescence in Situ hybridization)

FISH technique was used to avoid the need for cultivating a microorganism to recognize its presence and measure its distribution in a community. The microbial ecologists believe that there is potential to use molecular methods to understand microbial diversity. 16S rRNA sequences were used not only to permit culture-independent detection of population but also provide a means of observing pattern of their evolution.

Samples were collected from $85 \%$ of the Dead Sea and Red Sea mixture pond for hybridization experiments. Fixed samples were immobilized on glass slides by air drying. In situ hybridization was performed at $46^{\circ} \mathrm{C}$ for $90 \mathrm{~min}$ in a hybridization buffer containing $0.9 \mathrm{M}$ $\mathrm{NaCl}, 20 \mathrm{mM}$ Tris- $\mathrm{HCl}(\mathrm{pH} 7)$ and $1 \%$ SDS. Probe concentrations were $5 \mathrm{nmol} / \mu \mathrm{l}$. Probe EUB I (5'- FAM GCT GCC TCC CGT AGG AGT-3') and probe EUB II (5'-FAM GCA GCC ACC CGT AGG TGT-3') and EUB III (5'-FAM GCT GCC ACC CGT AGG TGT-3') were specifically for Eubacteria. For $\alpha$-proteobacteria we used probe (5'-LYS GGT AAG GTT CTG CGC GTT-3') and Arch. 915 probe is specific for Archea (5'-CAL160 GTC CTC CCC CGCCAA TTC CT-3'). Hybridization mixtures were removed and the slides were washed for $15 \mathrm{~min}$ in buffer containing $20 \mathrm{mM}$ Tris- $\mathrm{HCl}$, a millimolar concentration of $\mathrm{NaCl}$ and $0.01 \%$ SDS at $48^{\circ} \mathrm{C}$. The slides were examined under an epifluorescence microscope using different filters.

\section{Fatty Acids Analysis}

To understand the microbial communities, many researchers considered biomarkers as good indicator for this purpose. In this work the fatty acid composition of the lipids extracted from the $85 \%$ Dead Sea and Red Sea mixture pond was performed in an attempt to further characterize the microbial community and to define the presence of fatty acids that may be used as biomarkers for specific groups of bacteria.

The fatty acid methyl esters (FAME) were extracted with $1.25 \mathrm{ml}$ hexane-methyl-tertbutyl-ether $(1: 1, \mathrm{v}: \mathrm{v})$. The tubes were rotated for ten minutes, after that the upper phase including the FAME was transferred to new tubes. Then the FAME were analyzed on HP G1800B GCMS using an HP-5-MS column, the initial temperature being $120^{\circ} \mathrm{C}$ increasing at a rate of $5^{\circ} \mathrm{C}$ per min up to $240^{\circ} \mathrm{C}$ and then at a rate of $15^{\circ} \mathrm{C}$ per min up to $300^{\circ} \mathrm{C}$ for $20 \mathrm{~min}$. FAME were identified on the basis of their equivalent chain length. 


\section{RESULTS} mixtures

Field-scale experiments of microbial growth in the Dead Sea-Red Sea water

The field experiments showed that once a microbial bloom has formed in a Dead SeaRed Sea water mixture, it may continue for a long time.

A bloom of Dunaliella and halophilic Archaea in a mixture of Dead Sea water and Red Sea water (Tab. 1) supplemented with $1 \mu \mathrm{M}$ orthophosphate is expressed as a pigment concentrations (Figs. 3 and 4).

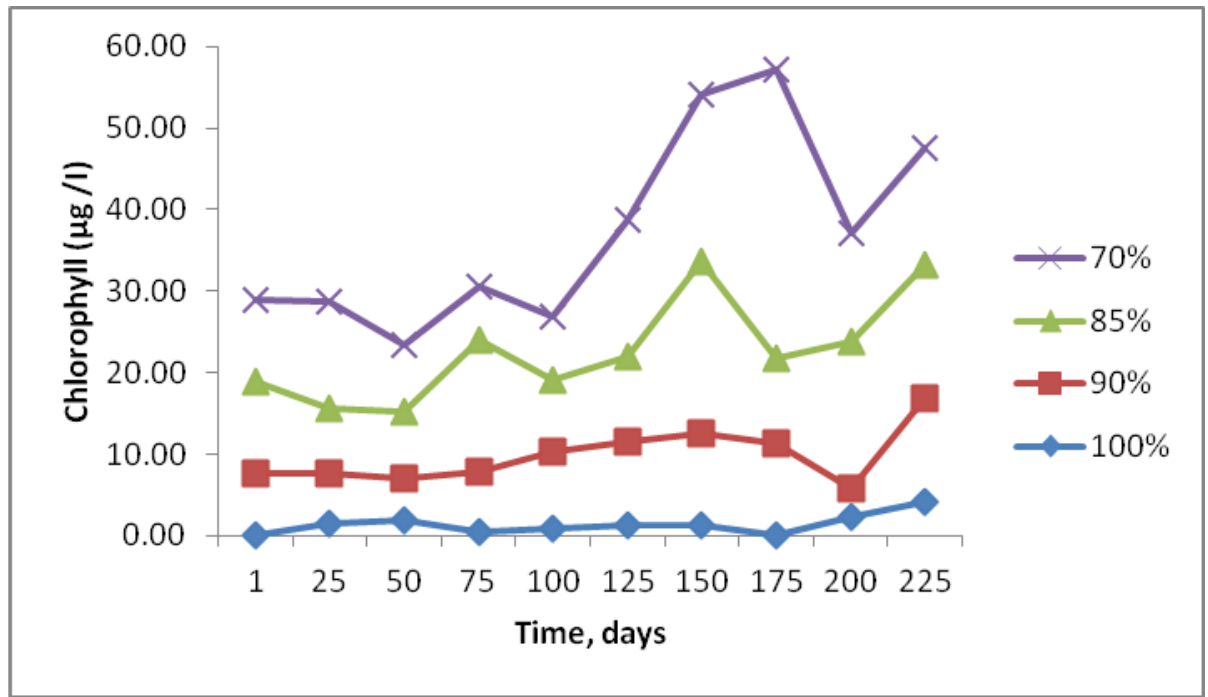

Figure 3: Algal bloom of Dunaliella in a mixture of different ratios of

Dead Sea water and Red Sea water expressed as chlorophyll.

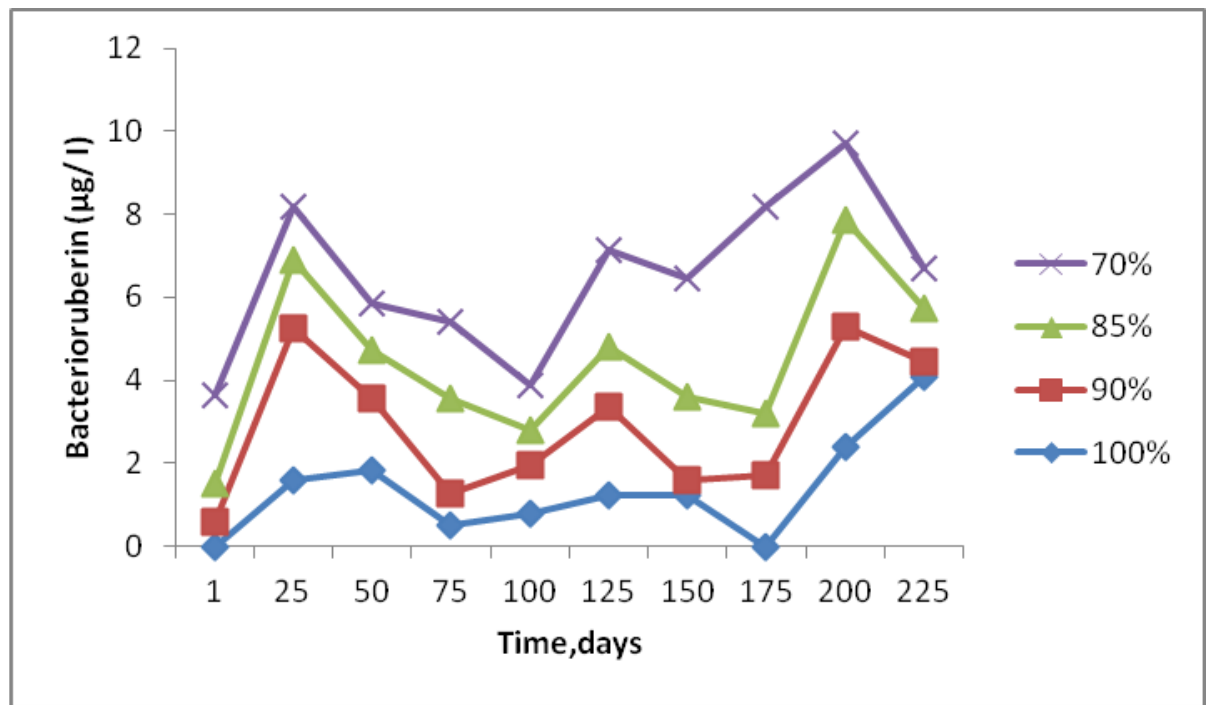

Figure 4: Halophilic Archaea bloom in a mixture of different ratios Dead Sea water and Red Sea water expressed as the concentration of bacterioruberin. 


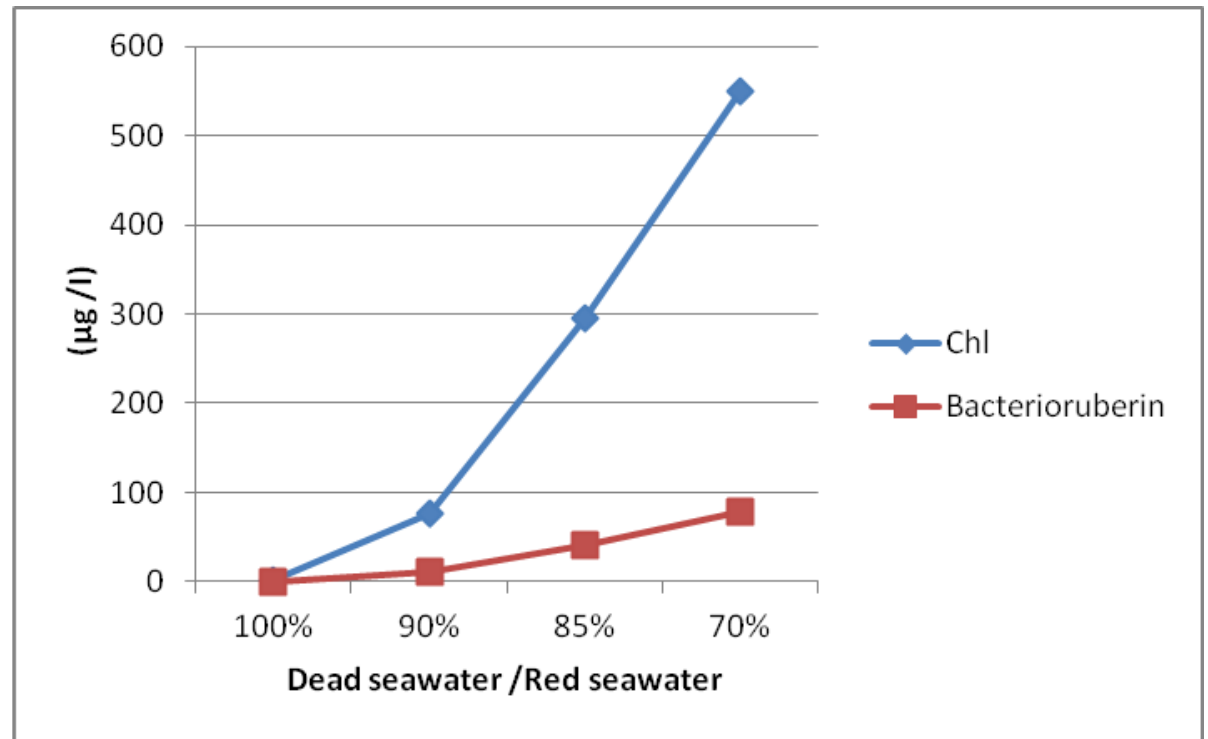

Figure 5: Concentrations of chlorophyll and Bacterioruberin $(\mu \mathrm{g} / \mathrm{L})$ 30 days time period.

In some of the ponds the dense biological communities developed within one-two months and the greatest extent of the algal and archaeal blooms was reached. These blooms depended on the degree of dilution and on the phosphate added. There is no significant biological growth in the $100 \%$ Dead Sea water pond, while very little occurred in mixtures of $90 \%$ Dead Sea water and $10 \%$ Red Sea water while clear cut growth in others mixtures. Algal pigment concentration reached values of up to $35.35 \mu^{-1}$ chlorophyll liter after six months $70 \%$ mixture, which started to appear after one-two months. Mass development of algae was followed by the growth of halophilic Archaea, which are heterotrophic microorganisms that develop at the expense of organic compounds produced by the autotrophic algae. The bacterioruberin's halophilic archaea (reach up to $1.8 \mu \mathrm{g} / \mathrm{l}$ ) imparted an intensely red color to the brine. The water in the ponds becomes highly turbid, and the algal chlorophyll and the archaeal bacterioruberin pigments confer brownish-green color to the water.

\section{mixtures}

Laboratory - scale experiments of microbial growth in Dead Sea - Red Sea water

The results of this laboratory experiment study, in which different types of mixtures were supplemented with different concentrations of orthophosphate, showed an inoculum of Dunaliella and halophilic archaea after incubation in the light for four weeks. Algae developed only when the concentration of Dead Sea water in the mixtures was below $90 \%$, and the rate at which the cells multiplied increased with decreasing salinity of the water mixture. The extent of the algal growth obtained was a function of the concentration of phosphate added in the laboratory experiment (Fig. 5). No further changes were noted when incubation was continued for three additional weeks. These results confirm open field experiments. 


\section{In Situ Hybridization Analysis of the samples}

The field experiment samples were first analyzed by DAPI staining and in Situ Hybirdization. The preliminary results are shown in figure 6a-d.

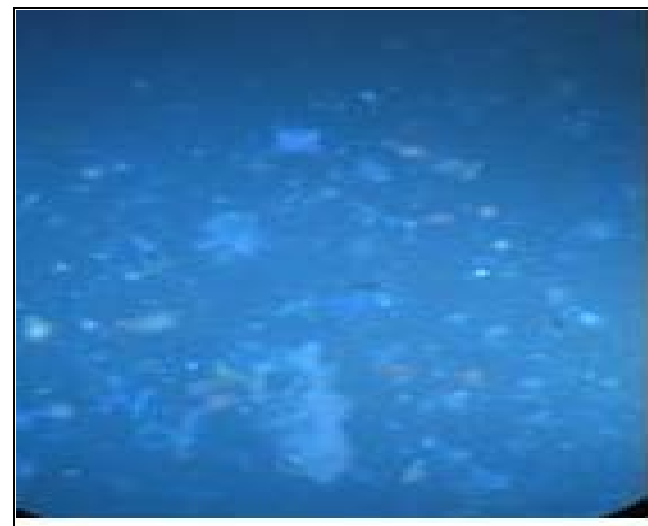

ZI

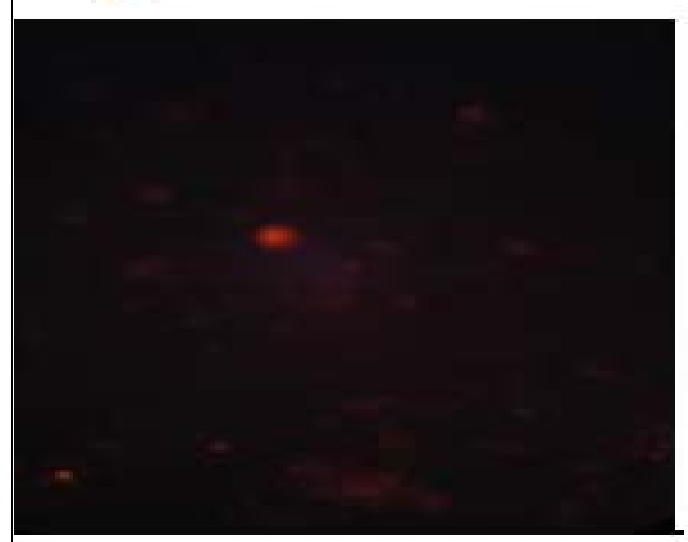

C

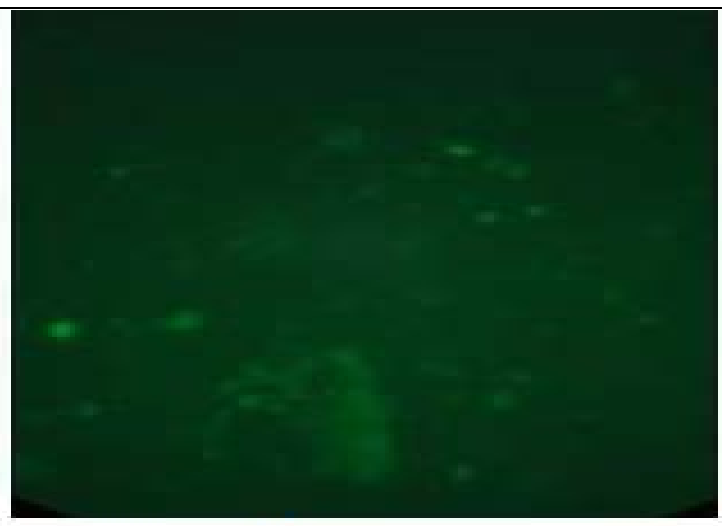

b

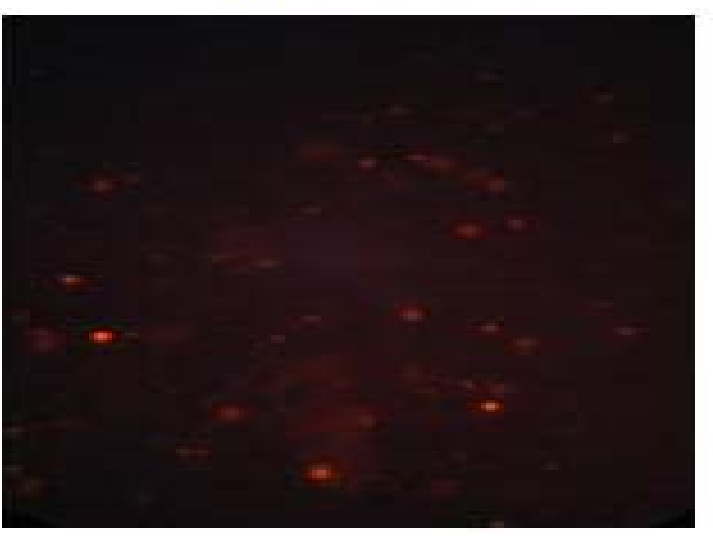

d

Figure 6 a-d: DAPI stain and hybridization signals for the same fields obtained with probes (EUB I, II, III, $\alpha$-proteobacteria and Arc915); a - DAPI, b - Eubacteria, c - $\alpha$-Proteobacteria, d - Archaea.

The signals obtained with all oligonucleotide probes were strong and indicated high cellular rRNA content. The community was dominated by bacteria which were detected by the different probes used. Archea were also present.

\section{Fatty Acids Analysis}

Fatty acids are excellent biomarkers for specific microorganisms and their fatty acids signature can be recognized in complex lipid mixtures derived from microbial communities. Table 3 shows the fatty acids composition (mol\% of total fatty acids extracted) of the different samples.

The fatty acids can serve as fingerprints of special microbial groups and can be used as a taxonomy signature for bacteria classification. They also carry information of the community structure. Fatty acids are valuable phenotypic indicators for characterizing pure culture. However, they often represent multiple-sources of environmental samples. 
The preliminary analysis of the fatty acid methyl esters (FAME) composition in the mixture samples were dominated by 14:0, 15:0, 16:0, 17:0 and 18:0 (Tab. 3). Iso - and antiso fatty acids (i.e., 15:0 iso, 15:0 antiso, 17:0 iso and 17:0 antiso) were major component of the total FAME (Tab. 3).

Table 3: Fatty acids composition (mol\% of total fatty acids extracted) of the different mixture samples.

\begin{tabular}{|l|c|c|c|c|c|}
\hline \multicolumn{1}{|c|}{ Fame } & S1 & S2 & S3 & S4 & S5 \\
\hline $14: 0$ methyl/14:0 iso & 0.9 & 0.6 & 0.5 & 0.8 & 0.5 \\
\hline $14: 0$ & 1.3 & 0.8 & 0.5 & 0.7 & 1.0 \\
\hline $15: 0$ iso & 30.9 & 29.6 & 30.2 & 27.5 & 45.7 \\
\hline $15: 0$ anteiso & 3.6 & 9.8 & 2.7 & 2.4 & 3.0 \\
\hline $15: 0$ & 1.0 & & 0.6 & 0.9 & 0.6 \\
\hline $16: 0$ methyl/16:0 iso & 15.7 & 8.1 & 16.7 & 20.7 & 17.8 \\
\hline $16: 0$ & 10.6 & 8.8 & 8.6 & 9.2 & 12.6 \\
\hline $17: 0$ iso & 17.9 & 25.5 & 26.9 & 26.0 & 4.4 \\
\hline $17: 0$ anteiso & 8.4 & 7.8 & 11.0 & 7.7 & 12.9 \\
\hline $17: 0$ & 0.6 & & 0.4 & 0.6 & \\
\hline $18: 0$ methyl/18:0 iso & & 0.8 & 0.4 & 0.6 & 0.5 \\
\hline $18: 1$ cis 9 & 2.1 & 0.9 & 0.3 & 0.7 & \\
\hline $18: 1$ cis 11 & 3.6 & 0.5 & & & \\
\hline $18: 0$ & 3.5 & 3.3 & 1.2 & 1.4 & 1.0 \\
\hline
\end{tabular}

As mentioned earlier, the analysis of fatty acids has been proven to be a valuable tool in the characterization of microbial communities, structures, nutritional status, metabolic activities and environmental stresses.

\section{DISCUSSION}

For many reasons, the Dead Sea was considered to be a hostile environment to life, being a far more extreme environment for life as compared to all other aquatic environments, particularly due to the higher salinity. Animals, plants and protozoa are absent. The primary producer Dunaliella and several species of halophilic Archaea may be found in this type of harsh environment (Oren, 1988). The general patterns of biological activity that occur in the aerobic water column of the Dead Sea and some of the interactive relationships between the biota are represented in figures 4 and 5 .

Dunaliella is one of the most salt-adapted algae known so far, which is why its bloom is associated with the development of Archaea, which use the expanses of organic material produced by algae under the favourable diluted condition. The results of this report confirmed the earlier findings of other authors (Oren and Gurevich, 1995), which were noticed after the rainy winters of 1980 and 1992 which were showed in simulation experiments (Figs. 4 and 5). Dunaliella produced glycerol, which is one of the organic compounds that provide osmotic stabilization. The halophilic Archaea used the glycerol as nutrient source. Dilution of the Dead Sea water by $30 \%$ Red Sea water caused the development of algal and archaeal bloom that impart a strong greenish-brown colour. The algal and archaeal densities exceeded any biological blooms that had been witnessed so far in the lake. 
The bioavailability of phosphate is accounted as a critical factor for the growth of microbial blooms in the lake. Dry and wet depositions are important sources of phosphate that enters the Dead Sea, in addition the direct input by the Jordan River and winter rain floods. Inorganic nitrogen is available in high contents as ammonium ions (Nissenbaum et al., 1990; Stiller and Nissenbaum, 1999). The concentration of dissolved phosphate in the Dead Sea was estimated by Stiller and Nissenbaum (1999) and Nissenbaum et al. (1990) of about one M. The determination of these ions' concentration is difficult due to the high molar concentration of salt. Our results from both indoor and outdoor simulation experiments demonstrated that the Dunaliella community highlight the important roles of phosphate as a key nutrient controlling the ecology of the Dead Sea (Figs. 4 and 5). Oren and Gurevich (1995), explained that any addition of new phosphate could enhance the algal growth and give chance for renewed growth of algal by formation of cyst-like structures, possibly zygotes, which sank to the bottom. Evidence showed that such thick-walled cysts serve as the inoculum that enables the rapid development of Dunaliella in the Dead Sea as soon as the upper water layers become diluted by freshwater floods.

As revealed by preliminary FISH analyses, bacteria and Archaea related to both Eubacteria and $\alpha$-protobacteria also form an important part of prokaryotic community inhabiting the Dead Sea. Among the interesting characteristics of the organism is the haloadaptation mechanism used to enable life under hypersaline conditions. All the halophilic and halotolerant aerobic bacteria characterized until 2002 produce and/or accumulate organic "compatible" solutes such as ectoine, glycine betaine, and other solutes, to provide the necessary osmotic balance. Synthesis and degradation of those solutes can be regulated according to the extracellular salt concentration, enabling a considerable degree of adaptability to changes in the salinity of the medium (Oren, $1999 \mathrm{~b}$ ).

Aerobic halophilic archaea accumulate potassium chloride in molar concentrations (Lanyi, 1974; Oren, 1999b). This strategy requires adaptations to intracellular processes to be functional at high salt concentrations. Proteins of the Halobacteriales are typically rich in acidic amino-acids, depleted of basic amino-acids, and relatively poor in hydrophobic amino acids. Such proteins generally require the presence of high salt concentrations for stability and activity (Lanyi, 1974). Accordingly, the microorganisms that possess these are unable to adapt to life below a (generally very high) minimal salt concentration. A similar strategy of adaptation to high salt was found in the obligatory anaerobic bacteria of Halanaerobiales order, phylogenetically affiliated with the low G+C branch of the Firmicutes (Oren, 1986; Oren, $1999 \mathrm{~b}$ ). Another interesting feature of this microorganism is the presence of two sulfonolipids in its membrane composition (Baronio et al., 2010). It is known that the modification of membrane lipid composition is an important aspect of haloadaptation, preserving membrane integrity and function at high salt concentrations.

Results from this study suggest that the lipid may be used as a chemotaxonomic marker for the detection of groups within the halophilic microbial community in saltern ponds and other hypersaline environments. Our results have recently shown that lipid analysis of the biomass lipid profile is a powerful experimental approach to obtain information on the types of halophilic microorganisms that inhabit brines. As glycolipids of extremely halophilic archaea may serve as chemotaxonomic markers for the classification of these organisms. Therefore, our conclusion is that the novel lipid may represent a useful biomarker to obtain both qualitative and quantitative information about the distribution of this genus in hypersaline environments. 
It is also interesting to understand the ecology of Salinibacter and the role it plays in the microbial community. Therefore, glycerol can be expected as one of the main nutrients available in hypersaline environments. It is produced in large quantities by the unicellular algae Dunaliella, which is the main or only primary producer in those habitats, including the experimental ponds. The use of glycerol by members of the Halobacteriaceae and Salinibacter had been demonstrated, and the overflow product formed by the latter was later identified (Elevi et al., $2007 \mathrm{~b}$ ).

The experiments with FISH from the experimental ponds, using universal primers for Archaea, showed that the community's diversity will significantly change according to the amount of Red Sea water poured into the hypersaline lake. The greatest diversity was observed when the Red Sea water represented $30 \%$ of the water mixture. The sample containing the smaller number of bands was that containing 80\% Dead Sea water and 20\% Red Sea water, probably because only a small number of species can tolerate such a high salinity. It is important to stress that, although Dead Sea-Red Sea mixtures at other ratios presented less diversity, it doesn't mean they were less populated; it is just an indication of the variety of species present, not of the total number of cells. Finally, the present team believed that if the Peace Conduit is to be implemented, changes in the archaeal community of the Dead Sea are expected.

\section{ACKNOWLEDGMENTS}

The authors wish to thank Mr. Alosufi A. for helping with the analyses, to biological department, Al Hussein Bin Talal University and for the financial support of the Scientific Research Support Fund, project no. S1/1/2009. 


\section{REFERENCES}

1. Anati D. A., Stiller M., Shasha S. and Gat J. R., 1987 - Changes in the thermo-haline structure of the Dead Sea: 1979-1984, Earth Planet Science Letters, 84, 109-121.

2. Baronio M., Lattanzio V. M. T., Vaisman N., Oren A. and Corcelli A., 2010 - The acylhalocapnines of halophilic bacteria: structural details of unusual sulfonate sphingoids, The Journal of Lipid Research, 51, 1878-1885.

3. Bodaker I., Sharon I., Suzuki T. M., Feingersch R., Shmoish M., Andreishcheva E., Sogin L. M., Rosenberg M., Maguire M. E., Belkin S., Oren A. and Beja O., 2010 - Comparative community genomics in the Dead Sea: an increasingly extreme environment, ISME Journal Multidisciplinary Journal of Microbial Ecology, 4, 399-407.

4. Dvorkin Y., Lensky N. G., Lyakhovsky V. and Gavrieli I., 2007 - Description and Benchmarking of the 1D Multi-Component Chemistry-Based Model for the Dead Sea (1DDS-POM), The Geological Survey of Israel, Report GSI/15/2007.

5. Elazari-Volcani B., 1943 a - Bacteria in the bottom sediments of the Dead Sea, Nature, 3853, 274-275.

6. Elazari-Volcani B., 1943 b - A Dimastigiamoeba in the bed of the Dead Sea, Nature, 3854, 301.

7. $\quad$ Elazari-Volcani B., 1944 - A ciliate from the Dead Sea, Nature, 3906, 335.

8. Elevi Bardavid R., Mana L. and Oren A., 2007 a - Haloplanus natans gen. nov., sp. nov., an extremely halophilic, gas-vacuolated archaeon isolated from Dead Sea-Red Sea water mixtures in experimental outdoor ponds, International Journal of Systematic and Evolutionary Microbiology, 57, 780-783.

9. $\quad$ Elevi Bardavid R., Ionescu D., Oren A., Rainey F. A., Hollen B. J., Bagaley D. R., Small A. M. and McKay C., 2007 b - Selective enrichment, isolation, and molecular detection of Salinibacter and related extremely halophilic Bacteria from hypersaline environments, Hydrobiologia, 576, 3-13.

10. Gavrieli I., Beyth M. and Yechieli Y., 1999 - The Dead Sea - A terminal lake in the Dead Sea rift: a short overview, in Oren A. (ed.), Microbiology and Biogeochemistry of Hypersaline Environments, CRC Press, Boca Raton, 121-127.

11. Gavrieli I., Lenski N., Yaari-Gazit N. and Oren A., 2002 - The impact of the proposed "Peace Conduit" on the Dead Sea, Evaluation of current knowledge on Dead Sea - seawater mixing, The Geological Survey of Israel, Report GSI/23/2002.

12. Gavrieli I. and Oren A., 2004 - The Dead Sea as a dying lake, in Nihoul J. C. J., Zavialov P. O. and Micklin P. P. (eds), Dying and Dead Seas, Climatic versus Anthropic Causes, Kluwer Academic Publishers, Dordrecht, 287-305.

13. Gavrieli I., Bein A. and Oren A., 2005 - The expected impact of the "Peace Conduit" project (the Red Sea - Dead Sea pipeline) on the Dead Sea, Mitigation and Adaptation Strategies for Global Change, 10, 3-22.

14. Nissenbaum A., Stiller M. and Nishri A., 1990 - Nutrients in pore waters from Dead Sea sediments, Hydrobiologia, 197, 83-89.

15. Oren A., 1988 - The microbial ecology of the Dead Sea, in Marshall K. C. (ed.), Advances in Microbial Ecology, Plenum Publishing Company, New York, 10, 193-229.

16. Oren A., 1999 a - Microbiological studies in the Dead Sea: future challenges toward the understanding of life at the limit of salt concentrations, Hydrobiologia, 405, 1-9.

17. Oren A., 1999 b - Bioenergetic aspects of halophilism, Microbiology and Molecular Biology Reviews, 63, 334-348.

18. Oren A., 2000 - Biological processes in the Dead Sea as influenced by short-term and longterm salinity changes Archives of Hydrobiology Special Issues Advances in Limnology, 55, 531-542. 
19. Oren A., 2003 - Biodiversity and community dynamics in the Dead Sea: archaea, bacteria and eucaryotic algae, in Nevo E., Oren A. and Wasser S. P. (eds), Fungal Life in the Dead Sea, A. R. G. Gantner Verlag, Ruggell, 117-140.

20. Oren A. and Gurevich P., 1995 - Dynamics of a bloom of halophilic archaea in the Dead Sea, Hydrobiologia, 315, 149-158.

21. Oren A. and Anati D. A., 1996 - Termination of the Dead Sea 1991-1995 stratification: biological and physical evidence, Israel Journal of Earth Sciences, 45, 81-88.

22. Oren A., Gavrieli I., Gavrieli J., Lati J., Kohen M. and Aharoni M., 2004 - Biological effects of dilution of Dead Sea water with seawater: implications for the planning of the Red SeaDead Sea "Peace Conduit”, Journal of Marine Systems, 46, 121-131.

23. Oren A., 2010 - The dying Dead Sea: The microbiology of an increasingly extreme environment, Lakes and Reservoirs Research and Management, 15, 215-222.

24. Steinhorn I., Assaf G., Nissenbaum A., Stiller M., Beyth M., Neev D., Garber R., Friedman G. M. and Weiss W., 1979 - The Dead Sea: Deepening of the mixolimnion signifies the overture to overturn of the water column, Science, 206, 55-57.

25. Stiller M. and Nissenbaum A., 1999 - Geochemical investigation of phosphorus and nitrogen in the hypersaline Dead Sea, Geochimica et Cosmochimica Acta, 63, 3467-3475.

26. Wilkansky B., 1936 - Life in the Dead Sea, Nature, 138, 467. 